\title{
Performance analysis of programmable machining strategies in milling operations of complex-shape pockets
}

\author{
Analiza efektywności programowanych strategii \\ frezowania złożonych kieszeni
}

\author{
MARIUSZ DEJA \\ JACEK EREMUS \\ MIECZYSŁAW SIEMIATKOWSKI *
}

DOI: https://doi.org/10.17814/mechanik.2017.10.124

\begin{abstract}
Presented is a selection method for determining the key process parameters for complex-shape pocket milling strategies using a definite tool set. The analysis concerning the influence of both axial and radial depth of cut on machining operation time was carried out in order to enable the selection of their proper setting values, considering the maximum effectiveness of selected tool sequence mostly in terms of time.

KEYWORDS: CAPP, features, tool sequences, process parameters
\end{abstract}

Adequate selection of tools and machining parameters is crucial to the efficiency of machining processes. The complexity of the task is greatly increased in the case of planning multi-procedural operations when an analytical determination of the required parameters optimizing the value of the objective function (minimization of time and cost of processing) is not feasible [7].

Improving the activities aimed at efficient production involves the use of continuously developed CAM technologies [8-10]. They offer strategies for the machining of workpiece geometry to be realized with the use of various tools on modern $\mathrm{CNC}$ machines with various kinematic structures. Their attribute is the ability to perform simulation analysis of many comparable machining strategies (generated paths of subsequent tools within the established sequences of their use). They support the choice of a machining option (within one of the alternatives), assuming the use of specific tools with established technology parameters. This applies to settings such as axial and radial depth of cut, resulting in the shortest machining time for the planned operation. Comparison of strategies and processing variants can be made according to either performance or cost.

\section{Research method and application example}

The optimum tool sequence and technological parameters for multistage milling of pocket assemblies realized within a single setup are most commonly determined using computer-aided manufacturing (CAM) systems [6, 10]. In the work [1], the CAM system was used for the quantitative analysis of machining strategies. In the process of processing the 2.5D pocket as a machining feature (technological elementary object)

* Dr hab. inż. Mariusz Deja (mdeja@pg.gda.pl), mgr inż. Jacek Eremus (jaceremu@student.pg.gda.pl) - Środowiskowe Studium Doktoranckie przy Politechnice Gdańskiej; dr inż. Mieczysław Siemiątkowski (msiemiat@pg.gda.pl) - Katedra Technologii Maszyn i Automatyzacji Produkcji, Wydział Mechaniczny Politechniki Gdańskiej
$F=\left\{f_{1}, f_{2}, \ldots, f_{m}\right\}$ using the set of tools $T=\left\{t_{1}, t_{2}, \ldots, t_{n}\right\}$ with diameters $d_{1}>d_{2}>\ldots d_{n}$, taking into account the constraints related to the sequences of cutting steps $i$ resulting from nesting the features $[1-3,5]$.

Fig. 1 shows an example of a part of an analyzed parts spectrum composed of the same feature types as in a research task [1] but with different geometrical dimensions.

The analyzed tool sequences were extracted from all alternative sequences considered for machining the $f_{1}$ feature (fig. 1), for which tools from the available tool set of $n=5$ (table I) can be applied, as suitable for machining the entire pocket.

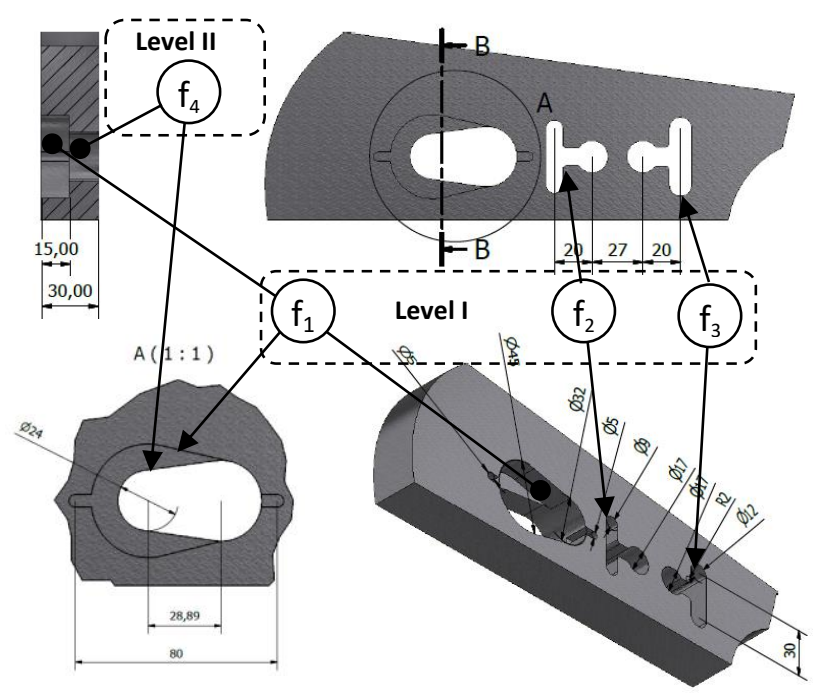

Fig. 1. Model of machined parts with geometrical dimensions

At the first stage of analysis, the $T_{\text {Mo }}$ machine's operating times were determined using the Heidenhain TNC-640 driver's simulator; the initial technological parameters included in the table I are used, while for each alternative tool sequence - table II.

Different methodology than in work [1] was adopted, using a currently working tool for processing available TOEs without the division into levels and processing of individual features. The standard machining cycles available in the Heidenhain TNC-640 control (fig. 2) are used in the part programming program. Calculations were made from the perspective of the influence of geometric figures on the machining time. In each case a fixed cutting speed of $120 \mathrm{~m} / \mathrm{min}$ is assumed, which corresponds to the machining of $\mathrm{C} 45$ carbon steel. The 
blade feed has been adopted according to the manufacturer's recommendations (table I).

TABLE I. List of tools and applied technological parameters

\begin{tabular}{|c|c|c|c|c|c|c|}
\hline $\begin{array}{c}\text { No. } \\
\text { of tool }\end{array}$ & $\begin{array}{c}\text { Tool } \\
\text { diame- } \\
\text { ter } d, \\
\mathrm{~mm}\end{array}$ & $\begin{array}{c}\text { Feed rate } \\
\text { per cutting } \\
\text { edge } t_{\mathrm{z}}, \\
\mathrm{mm} / \mathrm{cut}- \\
\text { ting edge }\end{array}$ & $\begin{array}{c}\text { Cutting } \\
\text { speed } \\
v_{\mathrm{c}}, \\
\mathrm{m} / \mathrm{min}\end{array}$ & $\begin{array}{c}\text { Radial } \\
\text { depth of } \\
\text { cut } a_{\mathrm{e}}, \\
\mathrm{mm}\end{array}$ & $\begin{array}{c}\text { Axial } \\
\text { depth of } \\
\text { cut } a_{\mathrm{p}}, \\
\mathrm{mm}\end{array}$ & $\begin{array}{c}\text { No. of } \\
\text { cutti- } \\
\text { nig } \\
\text { edges }\end{array}$ \\
\hline$t_{1}$ & 20 & 0.070 & 120 & 10 & 10 & 3 \\
\hline$t_{2}$ & 14 & 0.055 & 120 & 7 & 7 & 3 \\
\hline$t_{3}$ & 8 & 0.035 & 120 & 4 & 4 & 3 \\
\hline$t_{4}$ & 7 & 0.030 & 120 & 3,5 & 3,5 & 3 \\
\hline$t_{5}$ & 5 & 0.025 & 120 & 2,5 & 2,5 & 3 \\
\hline
\end{tabular}

Note: Eliminated $\square$ and selected $\square$ tools for analyzing the effectiveness of programmed machining strategies.

TABLE II. Summary of the analyzed sequences of tools for processing the set of machining features analyzed (TOE)

\begin{tabular}{|c|c|c|c|c|c|c|}
\hline $\begin{array}{c}\text { Sequence } \\
S_{k}\end{array}$ & $\begin{array}{c}\text { Time } \\
T_{M o}, \min \end{array}$ & \multicolumn{5}{|c|}{ Subsequent tools in k-th sequence } \\
\hline$S_{1}$ & 36.36 & $t_{1}$ & $t_{2}$ & - & - & $t_{5}$ \\
\hline$S_{2}$ & 35.42 & $t_{1}$ & - & $t_{3}$ & - & $t_{5}$ \\
\hline$S_{3}$ & 41.2 & $t_{1}$ & - & - & $t_{4}$ & $t_{5}$ \\
\hline$S_{4}$ & 50.35 & $t_{1}$ & - & - & - & $t_{5}$ \\
\hline$S_{5}$ & 40.23 & - & $t_{2}$ & - & - & $t_{5}$ \\
\hline$S_{6}$ & 41.23 & - & - & $t_{3}$ & - & $t_{5}$ \\
\hline$S_{7}$ & 45.18 & - & - & - & $t_{4}$ & $t_{5}$ \\
\hline$S_{8}$ & 58.48 & - & - & - & - & $t_{5}$ \\
\hline${ }^{*}$ For: $a_{\mathrm{e}}=0.5 d$ and $a_{\mathrm{p}}=0.5 d$. \\
\hline
\end{tabular}

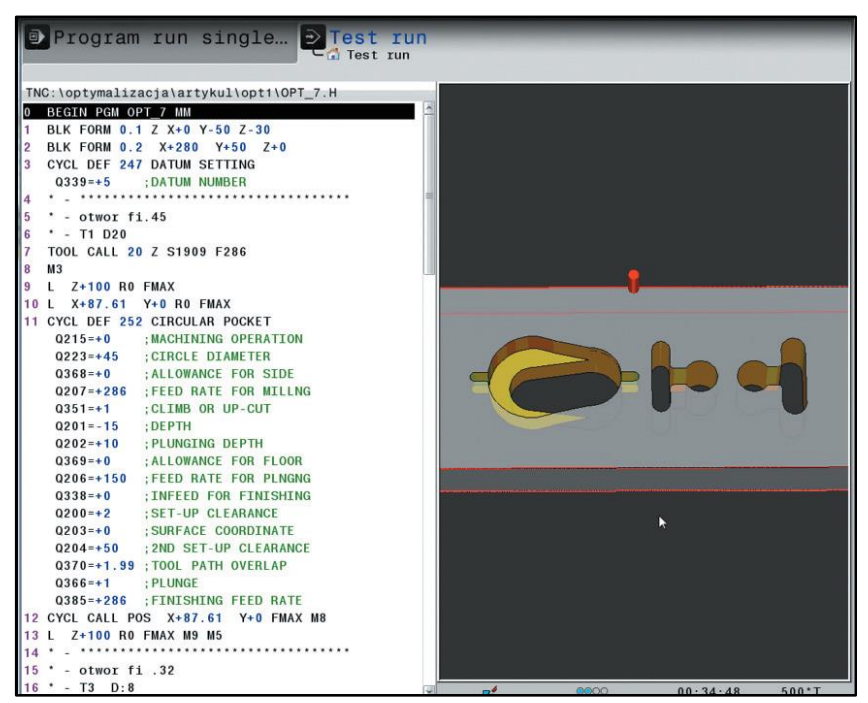

Fig. 2. Machining simulation with round pocket milling cycle declaration in Heidenhain TNC-640 controller simulator

\section{Research results and their evaluation}

The machine tool power is one of the basic limiting factors in planning a machining process for specific machines. The net cutting power (kW) in the analyzed case of C45 steel hardness of $32 \mathrm{HRC}$ was determined according to the known formula:

$$
P_{c}=\frac{a_{e} a_{\mathrm{p}} v_{f} k_{c}}{60 \cdot 10^{6}} \quad[\mathrm{~kW}]
$$

where: $a_{\mathrm{p}}$ - axial cutting depth in $\mathrm{mm}, a_{\mathrm{e}}$ - radial cutting depth in $\mathrm{mm}, v_{\mathrm{f}}$ - feed rate in $\mathrm{mm} / \mathrm{min}, k_{\mathrm{c}}-$ material factor determining cutting resistance in $\mathrm{N} / \mathrm{mm}^{2}$.
According to equation (1), increasing the cutting depth and feed rate is associated with an increase in power demand (fig. 3) with high material removal rate (fig. 4), as defined by the equation:

$$
Q_{v}=\frac{a_{\mathrm{p}} a_{\mathrm{e}} v_{f}}{1000} \quad\left[\mathrm{~cm}^{3} / \mathrm{min}\right]
$$

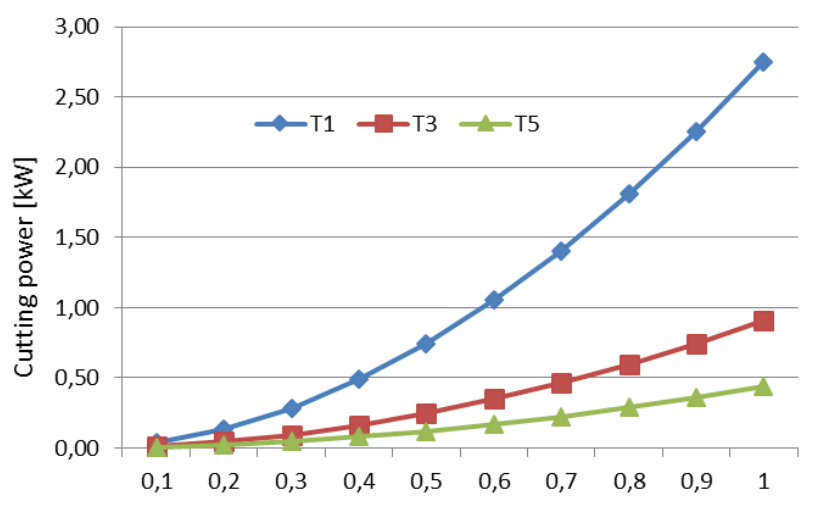

Fig. 3. Effective cutting power for subsequent tools of selected sequence $S_{2}$, for different values of radial depth of cut : $a_{\mathrm{e}}=w_{\mathrm{g}}$ $d$ and axial $a_{\mathrm{p}}=w_{\mathrm{g}} \cdot(d / 2)$

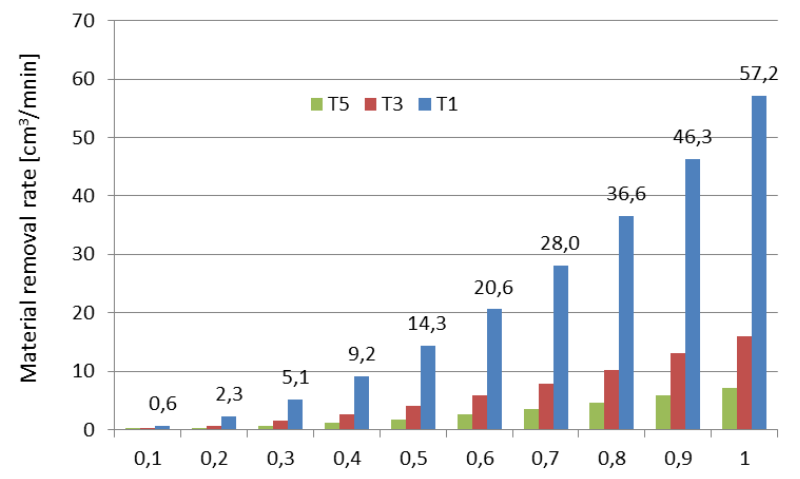

Fig. 4. Comparison of the material removal rate for individual tools from the analyzed sequence $S_{2}$ for different radial cutting depths $a_{\mathrm{e}}=w_{\mathrm{g}} \cdot d$ and axial depth of cut $a_{\mathrm{p}}=w_{\mathrm{g}} \cdot(d / 2)$

Increasing the cutting efficiency, however, is limited by the recommendations of the tool manufacturers, the geometry of the workpieces and the programming strategy of the workpiece, e.g. using programmable cycles. The machine-elicited machine operation times allowed the sequence to be selected with minimal processing time for all TOEs. Sequence No. 2 was selected from all sequences (table II) as follows:

$$
\min \mathrm{T}_{\mathrm{Mo}}(\mathrm{F}) \text {, where: } \mathrm{F}=\bigcup_{i=1}^{4} \mathrm{f}_{i}
$$

Analysis of subsequent process steps performed with the tools from Sequence No. 2 shows that there is a limit value of the radial depth of cut, after which the machine time cannot be shortened (table III). This is directly related to the geometric dimensions of the machining features and the diameters of the applied tools. With feature dimensions equal to tool diameters, machining time cannot be shortened, as shown in table III for $t_{\mathrm{M} 3}$ time and $t_{5}$ tool. 
TABLE III. Machine time values of subsequent machining operations from the selected sequence for variable radial depth of cut $a_{\mathrm{e}}$, at a fixed value of $a_{p}=0.5 d$

\begin{tabular}{|c|c|c|c|}
\hline$a_{\mathrm{e}}$ & $\begin{array}{c}t_{\mathrm{M} 1} \text { for } t_{1}, \\
\min \end{array}$ & $\begin{array}{c}t_{\mathrm{M} 2} \text { for } t_{3}, \\
\min \end{array}$ & $\begin{array}{c}t_{\mathrm{M} 3} \text { for } t_{5}, \\
\min \end{array}$ \\
\hline $0.1 d$ & 3.21 & 38.15 & 1.51 \\
\hline $0.2 d$ & 2.86 & 33.85 & 1.51 \\
\hline $0.3 d$ & 2.86 & 32.24 & 1.51 \\
\hline $0.4 d$ & 2.46 & 31.84 & 1.51 \\
\hline $0.5 d$ & 2.46 & 31.45 & 1.51 \\
\hline $0.6 d$ & 2.46 & 31.05 & 1.51 \\
\hline $0.7 d$ & 2.46 & 30.65 & 1.51 \\
\hline $0.8 d$ & 2.46 & 30.65 & 1.51 \\
\hline $0.9 d$ & 2.46 & 30.65 & 1.51 \\
\hline$d$ & 2.46 & 30.65 & 1.51 \\
\hline
\end{tabular}

Among technological cutting parameters, the cutting speed is most influenced by the cutting speed and the depth of cut is the lowest [7]. With respect to the cost criterion, it is necessary to determine the value of the working life of the replacement tool, which can be carried out using computer programs provided by utility companies.

The machining time at a fixed depth of cut $a_{\mathrm{p}}=0.5 d$ decreases markedly at the initial radial depth of cut (fig. 5 ) and then reaches the limit value for $a_{e}=0.7 d$. This value was adopted to the analysis of machining time variation for variable axial depth of cut $a_{\mathrm{p}}$, tested in the range of $0.1 \cdot(d / 2)$ to $d / 2$. As for $a_{e}$, the feature geometry determines the time of the operation (fig. 6). The increase in depth to $a_{p}=0.5 R$ leads to a significant reduction in machining time, with slight changes in the operation time above this depth.

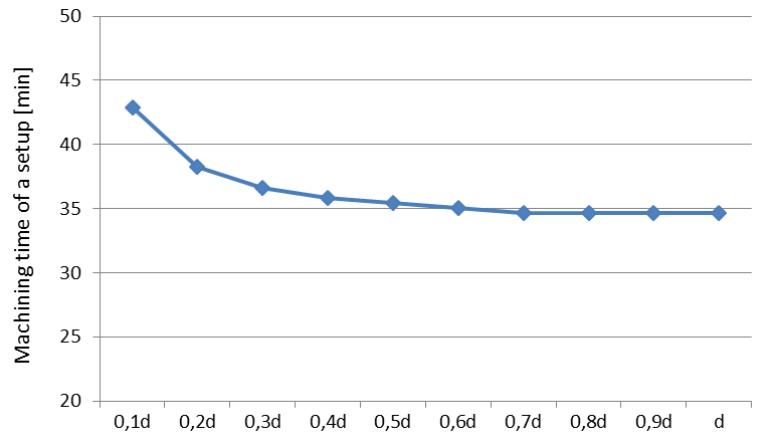

Fig. 5. Machining time at various settings of the depth $a_{\mathrm{e}}$ for fixed value of $a_{p}=0.5 d$

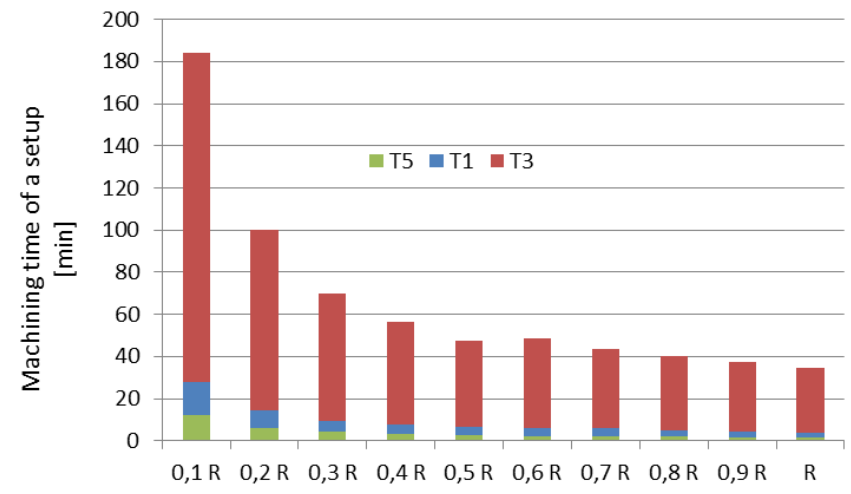

Fig. 6. Machine operating time at various depth settings $a_{e}$ for fixed value $a_{p}=0.7 d$

\section{Conclusions}

Presented planning method of multistage machining a compound surface area of complex pockets allows for a rational selection of settings for such process parameters as: axial and radial depth of cut, within a fixed sequence of tools derived from a definite, and in an industrial practice usually limited tool resource.

An analysis of subsequent steps of a selected tool sequence shows that there is a limit value for cutting depth beyond which machining time cannot be shortened, which is directly related to the geometric dimensions of the features and the diameters of the tools used. Further analyzes may be conducted in the direction of determining these values for parameterized models with different feature dimensions without machining simulations, but requiring artificial intelligence and algorithmic inference techniques [4].

Determining the machining costs requires determining the tool life under cut and taking into account the tool change times, tool depreciation costs and machine tool utilization costs.

\section{REFERENCES}

1. Bocheński T., Deja M., Siemiątkowski M.S. „Projektowanie strategii frezowania złożonych kieszeni w komponentach mechanicznych". Mechanik. 89, 10 (2016): pp. 1496-1497.

2. Chlebus E., Krot K., Kuliberda M. „Planowanie procesów technologicznych obróbki z zastosowaniem systemu ekspertowego". Archiwum Technologii Maszyn i Automatyzacji. 31, 4 (2011): pp. 115-123.

3. Deja M., Siemiątkowski M.S. „Feature-based generation of machining process plans for optimised parts manufacture". Journal of Intelligent Manufacturing. 24, 4 (2013): pp. 831-846. 4. Gupta A.K., Chandna P., Tandon P. „Optimization of machining parameters and tool selection in $2.5 \mathrm{D}$ milling using genetic algorithm". International Journal of Innovative Technology \& Creative Engineering. 1, 8 (2011): pp. 21-27.

5. Liu X., Li Y., Wang L. „Combining dynamic machining feature with function blocks for adaptive machining". IEEE Transactions on Automation Science and Engineering. 1, 2 (2016): pp. 828841.

6. Makhe A., Frank M.C. „Polygon subdivision for pocket machining process planning". Computers \& Industrial Engineering. 58, (2010): pp. 709-716.

7. Olszak W. „Obróbka skrawaniem”. Warszawa: WNT, 2008. 8. Skoczylas L., Skoczylas K. „Wpływ głębokości skrawania na czas maszynowy frezowania kieszeni kwadratowej". Mechanik. 89, 8-9 (2016): pp. 1162-1163.

9. Xu T., Chen Z., Li J., Yan X. „Automatic tool path generation from structuralized machining process integrated with CAD/CAPP/CAM system". International Journal of Advanced Manufacturing Technology. 80 (2015): pp. 1097-1111.

10. Zalewski A. „Zastosowanie technik automatyzacji programowania w systemach CAM do oceny efektywności frezowania CNC". Mechanik. 88, 3 (2015): pp. 36-43. 